\title{
THE ROLE OF REGION AND COASTAL LOCATION IN EXPLAINING METROPOLITAN POPULATION GROWTH DIFFERENTIALS DURING THE 1980s
}

\author{
William J. Serow and Steven M. O' Cain*
}

\begin{abstract}
There has recently been some speculation that the physical location of a community on the coast plays an equal or even more important role than does region in terms of the importance of geography upon population growth. This paper explores in empirical fashion the relative importance of coastal siting, as well as location, in the South or West, along with variables measuring economic base and demographic structure in explaining the relative rates of population growth in American metropolitan areas from 1980 to 1990.
\end{abstract}

\section{INTRODUCTION}

With the recent release of final population counts for metropolitan statistical areas (MSAs) in the United States, it is now possible to make a preliminary assessment of the area-specific characteristics that have been associated with population growth rate differentials during the 1980 s. As has been widely discussed both in the professional literature (Starsinic and Forstall 1989; Greenwood 1988) and in the popular press, overall population growth in the United States continues to be concentrated in the southern and western portions of the nation. The tendency of the population to disperse away from metropolitan areas during the previous decade seems to have reversed (again), so that the locus of growth is now in metropolitan counties (Frey 1988; Long and DeAre 1988; Agresta 1985). In addition to identifying geographic region as a means of differentiating among individual areas, demographers have speculated that a physical situation on or near the coast is also an important determinant of differential growth. Frey (1990) notes:

... (T)he familiar regional dichotomy between the slow-growing North on the one hand and the rapidly growing South and West on the other ... remains useful in explaining overall population redistribution trends. But it is less useful in explaining the recent changes in population growth than a new dichotomy that distinguishes the nation's coastal areas from its interior territory (p. 16).

\footnotetext{
* Director, Center for the Study of Population and Professor of Economics, The Florida State University, and Graduate Research Assistant, Center for the Study of Populations, The Florida State University, Tallahassee, Florida, respectively.
} 
and adds that this coastal phenomenon pertains to areas located on the Atlantic and Pacific coasts, but not to those located on the Gulf coast, which "... share many of the current demographic characteristics of America's heartland" (p. 17),

In addition to physical location, the likelihood remains that population growth rate differentials would also be reflected in differences in the initial demographic and economic characteristics of individual MSAs. Because the rate of population growth will reflect the influences of both natural increase (the difference between births and deaths) and net migration, it is essential that an effort be made to account for each of these components in the selection of explanatory variables.

With comparatively few exceptions, differences in natural increase within the United States should be accounted for largely by differences in race and age composition of the respective populations. Ceteris paribus, one would expect populations that are comparatively young to have a higher number of births and a lower number of deaths than a population of equivalent size that is comparatively old. Similarly, one would expect populations that contain a comparatively large share of ethnic minorities to have a higher number of births and a higher number of deaths than a population of equivalent size with comparatively few minorities. Thus, for example, in 1988 the fertility rate (births per 1,000 women aged 15 to 44) among white women stood at 63.0 versus 87.5 for women of all other races and 86.6 for black women (National Center for Health Statistics 1990a). In the same year, the age-adjusted death rate stood at 513.4 (per 100,000) for whites as opposed to 673.8 for all other races and 769.9 for blacks (National Center for Health Statistics 1990b).

The migration component of population change can probably be best accounted for by differences in economic opportunity among persons of working age and their dependents (Fields 1976; Herzog and Schlottmann 1983) and by a variety of amenity and climactic variables for the elderly (Serow 1987), many of which may be regarded as being subsumed by geographic location.

\section{DATA AND HYPOTHESES}

The dependent variable used throughout this paper is the recorded rate of population growth for each metropolitan area in the United States between April 1, 1980, and April 1, 1990 (referred to as "P"). The current (1989) MSA definition is utilized throughout the analysis, so there are no problems regarding additions to or deletions from the set of counties that comprise each individual area. The independent variables chosen may be logically grouped into three categories: 
1. A set of four dummy geographic variables that indicate whether the area is located in a) the South (SO); or b) the West (W) (U.S. Bureau of the Census regional definition); c) on the Atlantic or Pacific coast (C); and d) in Florida ${ }^{1}$ (F).

2. A set of four demographic variables that show a) the population of the MSA in 1980 (SI); b) the proportion of the 1980 population represented by persons of races other than white ${ }^{2}(\mathrm{~N})$; c) the proportion of the 1980 population represented by persons aged 18 to 24 (Y); and d) the proportion of the 1980 population represented by persons aged 65 or older (E).

3. A set of three economic variables that measure a) per capita personal income for 1980, adjusted for MSA-specific living costs (PCY); b) the unemployment rate for the MSA in 1980 (U); and c) the share of 1980 MSA employment engaged in the manufacturing sector (M).

All data listed under headings 2 and 3 are taken directly from 1980 Census of Population data at the county level and aggregated to the current MSA definition.

Some comment is in order regarding a few of these variables. Florida is treated as a separate variable due to the high level of population growth across the state and the relatively large number (19) of MSAs within it. ${ }^{3}$ Because Florida is so important in the migration behavior of older Americans (Biggar et al. 1984), it might be anticipated that the inclusion of this variable will influence both the comparative importance of age structure and the location in the southern region for MSAs. The income measure is constructed as the ratio of per capita income to median gross rent in the MSA. ${ }^{4}$ In effect, the aim here is to measure, albeit imprecisely, a level of income adjusted for living cost differentials. Although sporadic attempts have been made to provide a consistent set of intra-area cost-ofliving indices (see Cebula 1986), at present such universal indices do not exist. Finally, the share of metro-area employment in manufacturing was selected to serve as a relatively crude indicator of comparative employment prospects, reflecting the well-documented relative decline in this particular sector (Bluestone and Harrison 1982).

The hypothesized relationship between each of the independent variables and intercensal population growth may be summarized as follows:

1. All four geographic variables are expected to be positively associated with population growth (i.e., $\delta \mathrm{P} / \delta \mathrm{SO}, \delta \mathrm{P} / \delta \mathrm{W}, \delta \mathrm{P} / \delta \mathrm{C}, \delta \mathrm{P} / \delta \mathrm{F}>0$ ). 
2. To the extent that population dispersal has been reversed during the decade, initial (1980) population should be positively related to growth $(\delta \mathrm{P} / \delta \mathrm{SI}>0)$.

3. The effects of the share of the population made up of nonwhites may be viewed as indeterminant, as higher fertility levels can be at least partially offset by higher mortality $(\delta \mathrm{P} / \delta \mathrm{N} \gtrless 0)$.

4. The effect of the share of population aged 18 to 24 should be positive, owing to a potentially greater contribution to the number of births $(\delta \mathrm{P} / \delta \mathrm{Y}>0)$.

5. The effect of the share of population aged $65+$ may also be viewed as indeterminant, with a higher contribution to the number of deaths being offset in some areas by the attraction that large numbers of persons in this age group have on older in-migrants (Serow 1987) $(\delta \mathrm{P} / \delta \mathrm{E}$ $\gtrless 0$ ).

6. The role of both unemployment and manufacturing employment concentration should be negative with respect to population growth rates because both would suggest a comparative dearth of employment opportunities available to potential younger in-migrants $(\delta \mathrm{P} / \delta \mathrm{U}$ and $\delta \mathrm{P} / \delta \mathrm{M}<0)$.

7. Finally, the expected relationship between population growth and the constructed income measure is also indeterminant. While higher real income might be a drawing point to some, in actuality the availability of employment might be more relevant to younger persons, and costof-living considerations might be more important to older persons, whose nominal income level would be largely fixed, irrespective of current place of residence $(\delta \mathrm{P} / \delta \mathrm{PCY} \gtrless 0)$.

There is only a modest degree of correlation among independent variables, with the only value in excess of 0.4 being observed between an MSA's share of nonwhite population and a location in the South, reflecting historic patterns of U.S. population distribution by race.

Table 1 shows the mean value of the dependent and independent variables employed in this research, both for the entire universe of 281 MSAs and for various dichotomous groupings of the entire set chosen to reflect the regional or coastal locations of interest here. The final row of the table shows the overall intercensal growth rate for each respective grouping, which was weighted by the initial size of the corresponding metropolitan areas included within it. One might 
TABLE 1

Mean Values for Dependent and Independent Variables

\begin{tabular}{lrrrrrrrr}
\hline \hline & $\begin{array}{c}\text { Total } \\
(\mathrm{N}=281)\end{array}$ & $\begin{array}{c}\text { North } \\
(\mathrm{N}=116)\end{array}$ & $\begin{array}{c}\text { South and } \\
\text { West } \\
(\mathrm{N}=165)\end{array}$ & $\begin{array}{c}\text { Coastal } \\
(\mathrm{N}=55)\end{array}$ & $\begin{array}{c}\text { Non- } \\
\text { Coastal } \\
(\mathrm{N}=226)\end{array}$ & $\begin{array}{c}\text { Florida } \\
(\mathrm{N}=19)\end{array}$ & $\begin{array}{c}\text { Rest of } \\
\text { South } \\
(\mathrm{N}=100)\end{array}$ \\
\hline $\begin{array}{l}\text { Population in } \\
\text { 1980 (000s) }\end{array}$ & 613.0 & 731.8 & 529.4 & $1,332.1$ & 438.0 & 467.6 & 426.1 \\
$\begin{array}{l}\text { Real income } \\
\text { index }\end{array}$ & 84.6 & 86.6 & $83.2 *$ & 79.9 & 85.7 & 79.2 & 84.6 \\
$\begin{array}{l}\text { Percent on } \\
\text { coast }\end{array}$ & 19.6 & 12.9 & 24.2 & $\mathrm{NA}$ & $\mathrm{NA}$ & 52.6 & 10.0 \\
$\begin{array}{l}\text { Percent } \\
\text { nonwhite }\end{array}$ & 13.8 & 7.3 & 18.3 & 17.8 & 12.8 & 15.6 & 20.7 \\
$\begin{array}{l}\text { Percent aged } \\
\text { 18-24 }\end{array}$ & 14.6 & 14.8 & 14.5 & 14.2 & 14.7 & 12.7 & 14.8 \\
$\begin{array}{l}\text { Percent aged } \\
\text { 65+ }\end{array}$ & 10.7 & 11.1 & 10.4 & 11.2 & 10.6 & 16.2 & 9.8 \\
$\begin{array}{l}\text { Unemployment } \\
\text { rate (percent) }\end{array}$ & 6.7 & 7.1 & 6.4 & 6.8 & $6.6 \%$ & 5.4 & 6.0 \\
$\begin{array}{l}\text { Percent of } \\
\text { employment in } \\
\text { manufacturing }\end{array}$ & 21.3 & 26.2 & 17.8 & 18.7 & 21.9 & 11.2 & 21.2 \\
$\begin{array}{l}\text { Weighted } \\
\text { growth rate: }\end{array}$ & 11.6 & 3.0 & 20.0 & 15.2 & 8.9 & 32.3 & 14.2 \\
\hline $\begin{array}{l}\text { 1980 to 1990 } \\
\text { (percent) }\end{array}$ & 11.6 & & & & & \\
\hline
\end{tabular}

observe that the mean growth rate was significantly higher in the South or the West, in coastal MSAs, and in Florida.

\section{RESULTS}

Table 2 presents the results of a series of multivariate regression models relating each MSA's recorded intercensal population growth rate to those independent variables detailed previously. The first column shows the equation utilizing only the four demographic variables (N, SI, Y, E). These account for only about 10 percent of overall variance, although each individual variable, with the exception of initial population size, is significantly greater than zero. Thus, without regard to other (economic or geographic) variables, the relative size of both the nonwhite and the elderly populations exerts a positive influence on intercensal population growth as does the relative size of the younger population (as hypothesized). The other two subsets of variables are, in the aggregate, more powerful, and all independent variables are highly significant. As hypothesized, all four geographic variables (C, SO, W, F) exert a positive influence on 
TABLE 2

Summary of Regressions of the Intercensal Rate of Population Growth for Metropolitan Areas in the United States: 1980 to 1990

\begin{tabular}{|c|c|c|c|c|c|c|}
\hline & $\begin{array}{l}\text { Demographic } \\
\text { Variables } \\
\text { Only } \\
\text { (1) }\end{array}$ & $\begin{array}{c}\text { Geographic } \\
\text { Variables } \\
\text { Only } \\
\text { (2) } \\
\end{array}$ & $\begin{array}{c}\text { Economic } \\
\text { Variables } \\
\text { Only } \\
(3) \\
\end{array}$ & $\begin{array}{c}\text { All } \\
\text { Variables } \\
\text { Except FL } \\
\text { Dummy \# } \\
\text { (4) }\end{array}$ & $\begin{array}{c}\text { All } \\
\text { Variables } \\
(5) \\
\end{array}$ & $\begin{array}{c}\text { Excluding } \\
\text { Florida } \\
(\mathrm{N}=262) \\
(6) \\
\end{array}$ \\
\hline $\mathbf{N}$ & $\begin{array}{r}0.242 \\
(4.0)\end{array}$ & & & $\begin{array}{r}-0.028 \\
(0.5)\end{array}$ & $\begin{array}{r}0.006 \\
(0.1)\end{array}$ & $\begin{array}{r}-0.012 \\
(0.2)\end{array}$ \\
\hline SI & $\begin{array}{r}-0.004 \\
(0.1)\end{array}$ & & & $\begin{array}{r}-0.015 \\
(0.3)\end{array}$ & $\begin{array}{r}-0.008 \\
(0.1)\end{array}$ & $\begin{array}{r}0.008 \\
(0.2)\end{array}$ \\
\hline $\mathbf{Y}$ & $\begin{array}{r}0.200 \\
(3.0)\end{array}$ & & & $\begin{array}{r}-0.007 \\
(0.1)\end{array}$ & $\begin{array}{r}0.011 \\
(0.2)\end{array}$ & $\begin{array}{r}0.024 \\
(0.4)\end{array}$ \\
\hline E & $\begin{array}{r}0.293 \\
(4.2)\end{array}$ & & & $\begin{array}{r}0.225 \\
(3.9)\end{array}$ & $\begin{array}{r}0.048 \\
(0.8)\end{array}$ & $\begin{array}{r}-0.122 \\
(1.9)\end{array}$ \\
\hline C & & $\begin{array}{r}0.154 \\
(3.2)\end{array}$ & & $\begin{array}{r}0.179 \\
(3.5)\end{array}$ & $\begin{array}{r}0.115 \\
(2.4)\end{array}$ & $\begin{array}{r}0.153 \\
(2.8)\end{array}$ \\
\hline SO & & $\begin{array}{r}0.186 \\
(3.9)\end{array}$ & & $\begin{array}{r}0.190 \\
(2.9)\end{array}$ & $\begin{array}{r}0.093 \\
(1.6)\end{array}$ & $\begin{array}{r}0.105 \\
(1.6)\end{array}$ \\
\hline W & & $\begin{array}{r}0.390 \\
(7.9)\end{array}$ & & $\begin{array}{r}0.258 \\
(4.3)\end{array}$ & $\begin{array}{r}0.306 \\
(5.5)\end{array}$ & $\begin{array}{r}0.367 \\
(5.7)\end{array}$ \\
\hline$F$ & & $\begin{array}{l}0.582 \\
(12.3)\end{array}$ & & & $\begin{array}{r}0.439 \\
(7.6)\end{array}$ & \\
\hline $\mathrm{U}$ & & & $\begin{array}{r}-0.161 \\
(3.2)\end{array}$ & $\begin{array}{r}-0.172 \\
(3.5)\end{array}$ & $\begin{array}{r}-0.164 \\
(3.6)\end{array}$ & $\begin{array}{r}-0.168 \\
(3.2)\end{array}$ \\
\hline M & & & $\begin{array}{r}-0.356 \\
(6.6)\end{array}$ & $\begin{array}{r}-0.252 \\
(4.4)\end{array}$ & $\begin{array}{r}-0.138 \\
(2.5)\end{array}$ & $\begin{array}{r}-0.112 \\
(1.8)\end{array}$ \\
\hline PCY & & & $\begin{array}{r}-0.293 \\
(5.5) \\
\end{array}$ & $\begin{array}{r}-0.270 \\
(4.9) \\
\end{array}$ & $\begin{array}{r}-0.204 \\
(4.0) \\
\end{array}$ & $\begin{array}{r}-0.233 \\
(3.9) \\
\end{array}$ \\
\hline $\mathbf{R}^{2}$ & 0.091 & 0.466 & 0.326 & 0.468 & 0.550 & 0.423 \\
\hline
\end{tabular}

\# Cases in Florida treated as being in the South here.

Values in parentheses are t-statistics.

Coefficients are shown in their standardized (beta) form.

all four geographic variables (C, SO, W, F) exert a positive influence on metropolitan area population growth and by themselves explain 47 percent of the variance in metropolitan area growth. All three economic variables (PCY, U, M) exert a negative influence, as hypothesized for the rate of unemployment and the share of employment in manufacturing. Thus, without regard to other (demographic or geographic) variables, the relative level of real income exerts a negative influence on intercensal population growth. Collectively, these three variables explain a third of the variance in metropolitan area growth.

The next two columns show the results for the entire sample of MSAs, simultaneously incorporating the effects of all variables excluding the dummy showing a Florida location in one case, and in the second, the effects of all 11 in- 
dependent variables. Thus, in Column 4, the 19 Florida MSAs are treated as being in the South, whereas in Column 5, they are not .

In both models 4 and 5 , the principal outcome is to substantially weaken the role of the demographic variables. In the specification of the model where Florida MSAs are not considered separately, but simply as being in the South, only the share of population aged 65 and over (E) remains with a strong and significant degree of association with overall population growth. On the other hand, all coefficients of both geographic and economic variables are of approximately the same order of magnitude and of the same sign as in models 2 and 3.

When a Florida location is treated as a separate dummy variable (model 5), the coefficients of all four of the demographic variables become extremely small and totally without significance. Otherwise, there is little difference between this specification and models 2 to 4, except that, as might be expected, the coefficient for SO is much smaller and no longer statistically significant, thereby suggesting that most of the influence of a southern location on metropolitan area population growth and of the concentration of the elderly in an area are really examples of what might be termed a "Florida effect." Thus, when explicit account is made of those MSAs located in Florida, the explanatory power of a southern location is diminished to the point of statistical insignificance, and the initial importance of a large elderly population in explaining population growth is materially altered. Indeed, in a separate regression omitting the 19 Florida MSAs from the universe (see Column 6), the coefficient of E becomes negative and (weakly) significant, so that the relationship between concentrations of the elderly and population growth becomes the opposite of what it had first appeared to be. This result effectively demonstrates the contention (Rogers and Woodward 1988) that elderly population concentration can be symptomatic of either rapid population growth or of incipient population decline.

\section{CONCLUSIONS}

This paper set out to establish the pattern of association between location (with respect to region and coastal setting) and the rate of population growth for metropolitan areas in the United States during the 1980s. Additionally, it has explored the importance of economic (unemployment, industrial mix, and real income) and demographic (racial mix, initial population size, age structure) variables in accounting for such growth rate differentials. Our findings suggest that while coastal location is important, it in no way diminishes the role of regional differences between "Rust Belt" and "Sun Belt," especially when explicit treatment is afforded to MSAs in Florida. Furthermore, economic measures also 
play an important role, independent of geography. As would be expected from economic theory, growth is less likely to occur in areas with high levels of unemployment. Consistent with structural changes in the American economy, population growth is also concentrated in areas with minimal reliance on manufacturing for their economic bases. The only demographic variable among those included here that made any contribution to the disentangling of growth differentials was the share of an area's 1980 population represented by persons aged 65 and over. In the initial model specification that did not explicitly include Florida location, this measure exerted a significantly positive influence on the observed rate of population growth. However, net of Florida location, the influence of a large older population became significantly negative.

In short, MSAs with relatively large numbers of older residents are clearly heterogeneous with respect to location, to the demographic and economic forces that brought about this type of age structure, and ultimately to their recorded rate of population growth during the most recent intercensal period.

\section{ENDNOTES}

1. In all regression results to be reported here, whenever "Florida" is used as an independent variable, the 19 MSAs in the state are given a value of zero for the dummy variable "South."

2. In addition to showing the proportion of the population of white, black, Asian, and native American races, this variable will also be indicative of the relative number of persons of Hispanic ethnicity, since many such individuals reported their race as "other" in the census questionnaire.

3. While similar arguments could be advanced on behalf of other states, most notably California and Texas, separate treatment of neither afforded results as dramatic and consistent as those for Florida. The results of these modelling efforts are not included in this paper, but are available from the senior author upon request.

4. These were further transformed into an index form, with the highest observed ratio (Gadsden, Alabama: 36.1) being set equal to unity and all others correspondingly lower. 


\section{REFERENCES}

Agresta, Anthony. "The Migration Turnaround: End of a Phenomenon?" Population Today 13 (January 1985): 6-7.

Biggar, Jean C., Donna Cowper, and Dale Yeatts. "Migration Patterns and Selectivity, 1955-60, 1965-70, 1975-80 and Decade Trends." Research on Aging 6 (1984): 163-188.

Bluestone, Barry, and Bennett Harrison. The Deindustrialization of America. New York: Basic Books, 1982.

Cebula, Richard J. "A Living Cost Index for SMSAs." Social Science Quarterly 67 (1986): 887-891.

Fields, Gary. "Labor Force Migration, Unemployment and Job Turnover." Review of Economics and Statistics 58 (1976): 407-415.

Frey, William H. "The Re-emergence of Core Region Growth: A Return to the Metropolis?" International Regional Science Review 11 (1988): 261-267. . "Metropolitan America: beyond the Transition." Population Bulletin 45 (July 1990): passim.

Greenwood, Michael J. "Changing Patterns of Migration and Regional Economic Growth in the US: A Demographic Perspective." Growth and Change 19 (1988): 68-87.

Herzog, Henry W., and Alan M. Schlottmann. "Migrant Information, Job Search, and the Remigration Decision." Southern Economic Journal 50 (1983): 43-56.

Long, Larry, and Diana DeAre. "US Population Redistribution: A Perspective on the Nonmetropolitan Tumaround." Population and Development Review 14 (1988): 433-450.

National Center for Health Statistics. "Advance Report of Final Natality Statistics, 1988." Monthly Vital Statistics Report 39 (August 15, 1990a).

"Annual Summary of Births, Marriages, Divorces and Deaths: United States, 1989." Monthly Vital Statistics Report 38 (August 30, 1990b).

Rogers, Andrei, and Jennifer Woodward. "The Sources of Regional Elderly Population Growth: Migration and Aging-in-Place." The Professional Geographer 40 (1988): 450-459.

Serow, William J. "Determinants of Interstate Migration: Differences between Elderly and Nonelderly Movers." Journal of Gerontology 42 (1987): 95-100.

Starsinic, Donald E., and Richard L. Forstall. "Patterns of Metropolitan Area and County Population Growth: 1980-1987." In Current Population Reports, Series P-25, no. 1039 (1989). Washington, D.C.: U.S. Bureau of the Census, 1989. 